\title{
Follow up of the pancreatic structural alterations in a rat model of andropause induced by bilateral orchiectomy after different time periods
}

\section{Original Article}

\author{
Zienab A. Gouda ${ }^{1}$, Nesma I. El-Naseery ${ }^{2}$, Mohamed E. Ali Khalifa ${ }^{1}$ \\ ${ }^{1}$ Department of Histology and Cell Biology, Faculty of Medicine, ${ }^{2}$ Department of Histology \\ and Cytology, Faculty of Veterinary Medicine, Zagazig University, Zagazig, Egypt
}

\begin{abstract}
Introduction: The pancreas and male gonads shared similar utilities.

Aim: To follow-up the pancreatic structural alterations after orchiectomy on different times.

Materials and Methods: Twenty-four rats were allocated into sham-operated (Group I, n=6) and orchiectomized (Orx) (Group II, $\mathrm{n}=18$ ). After 2 weeks of rest, the Gr II was equally re-distributed into subgroups IIa, IIb, and IIc depending on sacrifice time (3,6 and 9 weeks, respectively). The pancreatic specimens were processed and stained with H\&E and were immunostained with anti-insulin and glucagon proteins and anti-single-strand DNA (ss-DNA). Body masses, serum testosterone, fasting plasma glucose levels, oxidant and antioxidant markers were measured. The optical density of insulin immunopositive reaction and immunopositive area \% of insulin, glucagon, and ss-DNA were realized with image analyzer. Data were statistically analyzed by ANOVA's and Tukey's test.

Results: This study revealed that the orchiectomized rats were hyperglycemic. The oxidative stress was significantly elevated while the antioxidant enzyme was significantly decreased. Structurally, in Gr IIa, the acini were deformed and shrunken. The acinar cells had less basophilic cytoplasm with small and darkly basophilic nuclei, while the islets cells appeared deeply acidophilic with small darkly stained nuclei. The apoptotic cells were observed in some acinar cells and in cells peripherally located in islets. The positive area $\%$ of the $\beta$ cell was non-significantly decreased, whereas the positive area $\%$ of $\alpha$ cell was significantly decreased. Additionally, the positive area\% of apoptotic cells was significantly increased. Gr IIb and GrIIc revealed the same structural changes as in GrIIa.

Conclusion: Orchiectomy-induced testosterone deficiency affects the exocrine and endocrine pancreatic portions, both with a risk for pancreatogenic diabetes (type III). Therefore, we should be more cautious before performing orchiectomy in humans or animals.
\end{abstract}

Received: 02 March 2018, Accepted: 15 April 2018

Key Words: Andropause, orchiectomy, pancreas, rats.

Corresponding Author: Nesma I. El-Naseery, Department of Histology and Cytology, Faculty of Veterinary Medicine, Zagazig University, Zagazig, Egypt, Tel.: 002 01222945073, E-mail: nesmaelnasery@yahoo.com.

ISSN: 1110-0559, Vol. 41, No. 3

\section{INTRODUCTION}

Andropause (a decline in serum total testosterone level less than $3.5 \mathrm{ng} / \mathrm{mL}$ or in free testosterone (T) level less than $72 \mathrm{pg} / \mathrm{mL}$ ) has become a true health problem as the $\mathrm{T}$ level falls progressively from the late 20 's or even, mid 20's and continues across the rest of men life. Despite decline of $\mathrm{T}$ level occurs slowly and subtly ${ }^{[1,2]}$, many adverse effects including, cognitive decline, erectile dysfunction, a decrease in lean mass and bone density or even osteoporosis, and mild anemia are documented ${ }^{[3,4]}$.

In several medical disorders including; prostatic cancer and suspended testicular tumor, androgen deprivation therapy (ADT) is urgent. ADT is mainly dependent on suppression of androgens of testicular origin ${ }^{[5]}$. ADT is performed via two ways: surgical ablation of testes or medical androgen blockade via synthetic analogs of gonadotropin-releasing hormone ${ }^{[6]}$. Regardless of the causes or ways, ADT raises the risk of oxidative stress that could cause brain damage, diabetes mellitus (DM ) and heart disease $\mathrm{e}^{[7-10]}$.

In concert, the pancreas and male gonads shared similar utilities. The sex-determining region $\mathrm{Y}$ (Sry)box-containing (Sox) factors especially SOX9 has been identified in pancreogenesis. SOX9 is responsible for endocrine differentiation and maintenance of the embryonic and adult pancreatic ductal state. The roles of SOX9 in both the developing and mature pancreas have been covered in the review of Seymour ${ }^{[11]}$. Moreover, testosterone exerts a natural protective antioxidant and anti-apoptotic activities in many tissues especially the pancreas ${ }^{[1]}$. Recently, pancreatic $\beta$ cell dysfunction is proven to be 
responsible for male sexual dysfunction in humans and animals. Excessive production of radical oxygen species (ROS) in testicular cells is documented in diabetic patients. Increased ROS and apoptosis can induce male infertility. Also, DM increases germ cells apoptosis and interrupts spermatogenesis $^{[13]}$. Decreased testosterone levels, DM type II, and even insulin resistance were found to be linked. So, some investigators considered steroid hormone therapy as a new approach for the treatment of $\mathrm{DM}^{[14,15]}$. Even, prevention of obesity and DM by dehydroepiandrosterone (DHEA) administration is considered as a line of treatment ${ }^{[16]}$. In the meantime, DHEA is currently widely accepted as a "treatment for aged men" ${ }^{[17]}$. Finally, several cross-sectional studies with different methodologies could prove an inverse relationship between levels of serum free testosterone and fasting insulin hormones ${ }^{[3,18,19]}$. The previous data spurred us to mimic andropause (testosterone deficiency) in rats via surgical orchiectomy and follow up the structural alterations that may occur in the pancreatic structure and function after different time periods.

\section{MATERIALS AND METHODS}

\section{Animals}

The experimental protocol was performed according to the guidelines of the ethical committee of Zagazig University, Egypt. Middle-aged male Wistar rats $(n=24$; 10-12 months old; $441.95 \pm 98.82$ g mean body mass), housed in the Breeding Animal House, in the Faculty of Medicine, Zagazig University under a strict care at a temperature of $25 \pm 2^{\circ} \mathrm{C}$ and $12: 12 \mathrm{~h} \mathrm{light/dark} \mathrm{cycle}$ were utilized. The animals fed on a soy-free diet and water ad-libitum.

\section{Bilateral orchiectomy procedure (scrotal approach)}

We followed the method described by ${ }^{[20]}$. After anesthesia with $20 \mathrm{mg} / \mathrm{kg}$ dose of sodium thiopental (Pentothal), a small incision was made at the tip of the scrotum. The blood vessels and vas deferens were ligated with 4-0 absorbable surgical thread. Then, the right testis, epididymis and a piece of vas deferens were removed. Afterwards, the remaining tissues were returned into the scrotal sac and the skin incision was sutured with nonabsorbable surgical thread. The same procedure was repeated for the left testis. In the sham-operated group (Gr I), the testicular fat pads were only excised. The animals were singly separated and carefully monitored to avoid chewing sutures. The rats were given $25 \mathrm{mg} /$ $\mathrm{kg} / 12 \mathrm{~h}$ metamizole sodium as an analgesic and received IM injection of $4000 \mathrm{IU} / \mathrm{kg} / 24 \mathrm{~h}$ ampicillin for 2 days. The wound dressing was also applied every day for a week. All rats were rested for two weeks under specified-pathogenfree conditions.

\section{The experiment}

Rats were allocated into two main groups after one-week-acclimatization. Sham-operated group (Group I, n=6) underwent only mobilization of testicular fat pads and orchiectomized group (Group II, n=18) underwent bilateral orchiectomy and epididymectomy via scrotal approach. After resting for two weeks, the Gr II was re-distributed into three equal subgroups: IIa, IIb, and IIc depending ondifferent sacrifice times: 3, 6 and 9 weeks, respectively.

\section{Biochemical analysis}

All chemicals and kits were purchased from Al Gomhoira co, El Mohafza st, Zagazig, Egypt. After 8-hours fasting, blood samples $(6 \mathrm{ml}$ /animal $)$ were collected by retro-orbital puncture just before sacrifice by decapitation at daytime, same hour (5 p.m.). Blood samples were divided into two parts; the first part was left to clot overnight at room temperature, then centrifuged at 3000 rpm for $10 \mathrm{~min}$ for separation of serum and the second part was collected in heparinized tubes $10 \mathrm{~min}$ at $4000 \mathrm{rpm}$ and then, aspirate off the plasma and the erythrocyte lysate was prepared for estimation of superoxide dismutase (SOD). Separated plasma and sera samples of all the animals were stored at $-80 \mathrm{C} \circ$ until used.

\section{Measurement of serum testosterone level}

Serum testosterone level was measured with the use of an enzyme-linked immunosorbent assay kit [Testosterone (mouse/rat) ELISA Kit, Cat No: MBS843463; MyBioSource] according to the kit manufacturer's instructions and expressed as $\mathrm{ng} / \mathrm{mL}$.

\section{Measurement of plasma glucose level}

Fasting plasma glucose level was measured using glucose oxidase method (Spinreact, Girona, Spain). The values were expressed as $\mathrm{mg} / 100 \mathrm{ml}$.

\section{Measurement of oxidative and antioxidant markers}

Following the manufacturer's instructions, SOD (an antioxidant marker) and Malondialdehyde (MDA); a lipid peroxidation marker levels were measured using commercially available kits (Cat No. K335-100; and Cat No. K739-100; Biovision Inc, San Francisco, USA, respectively). Colorimetrically, the absorbance of SOD was at $450 \mathrm{~nm}$ and the absorbance of MDA was at $532 \mathrm{~nm}$.

\section{Histological analysis}

The pancreatic specimens were immediately fixed in $10 \%$ neutral buffered formalin, dehydrated in ascending grades of ethanol, cleared in xylol and embedded in paraffin wax. Finally, $3 \mu \mathrm{m}$ thick paraffin sections were cut and stained with Hematoxylin and Eosin $(\mathrm{H} \& \mathrm{E})^{[21]}$.

\section{Immunohistochemistry}

The immunohistochemical staining with antiinsulin protein, anti-glucagon protein, and anti-ssDNA was performed to detect the $\beta$ and $\alpha$ cells and apoptotic cells, respectively. In brief, the streptavidin-biotin immunostaining procedure was performed according to manufacturers's instructions. The paraffin sections of about $3 \mu \mathrm{m}$ in thickness were deparaffinized and 
rehydrated. Sources, dilutions of the primary antibodies, antigen retrieval, and heating conditions were represented in Table 1. Endogenous peroxidase was blocked via methanol containing $3 \% \mathrm{H}_{2} \mathrm{O}_{2}$ for $15 \mathrm{~min}$ at room temperature followed by washing in distal water, 3 times, 2 min each. The protein block reagent (normal mouse serum) was added in a humid chamber for 30 min and removal of excess block reagent was done. The sections were incubated with primary antibodies overnight at $4^{\circ} \mathrm{C}$, followed by washing with phosphate buffered saline and incubated with the secondary antibody (goat anti-rabbit IgG) (Cat No: PAB 10822; Abnova; USA). The sections were washed, three times, $5 \mathrm{~min}$ each, followed by treatment with streptavidin-biotin complex for $30 \mathrm{~min}$ at room temperature. The reactions were visualized with $\mathrm{DAB}$ solution containing $0.006 \% \mathrm{H} 2 \mathrm{O} 2$. Finally, the sections were lightly counterstained with hematoxylin.

\section{Image analyses and morphometric study}

The image analyzer computer system Leica Qwin 500 (Leica Ltd, Cambridge, UK) in the Image Analyzing Unit of the Pathology Department, Faculty of Dentistry, Cairo University, Egypt, was used for estimation of the insulin optical density, areas $\%$ of immunoreactivity for insulin, glucagon and ssDNA in the pancreatic islets in all examined groups. Three non-overlapped high-power fields $(\times 400)$ from three immunostained different sections of each animal ( $\mathrm{n}=6$ per group) were examined. The immunopositive areas were masked with a blue color in a binary manner by using the color detection in a standard measuring frame area equal to $118476.6 \mu \mathrm{m}^{2}$.

\section{Statistical analysis}

All the experimental obtained data were statistically analyzed by Analysis of Variance (ANOVA) using SPSS program version 16 (Chicago, USA). Data are presented as the mean \pm standard error (SE) and followed by Tukey's post hoc test to compare means. Differences were considered to be significant when $P$ value $\leq 0.05$.

\section{RESULTS}

\section{General observations}

The orchiectomized rats appeared tired and exhausted. Low activity of rats and tendency to sleep especially after meals were noticed. In Table 2 , the body masses of the Gr IIa were statistically decreased by comparison with the Gr I. While, the Gr IIb and Gr IIc showed a significant increase of body masses when compared with Gr IIa.

\section{Biochemical results}

Table 3 showed the effects of bilateral orchiectomy after different time periods on biochemical parameters. Compared to the Gr I, fasting plasma glucose levels of $\mathrm{Gr}$ IIa, IIb, and IIc were significantly increased while, serum free $\mathrm{T}$ levels were significantly decreased.

\section{The antioxidant and oxidative stress results}

In Table 3, compared to Gr I, SOD level was significantly decreased in the Orx groups. On the other hand, the level of the oxidative stressor MDA was significantly increased in Gr IIa when compared with the Gr I. In Gr IIb, the increment of MDA level was significant when compared with the Gr I and non-significant with Gr IIa. In Gr IIc, the increment of MDA level was significant when compared with both of Gr I and Gr IIa.

\section{Histological evaluation of pancreatic tissue}

\section{H\&E stained sections}

Histological examination of the control pancreas revealed a distinctive multi-lobulated organ. The lobules were separated by delicate connective tissue septa that housed blood and lymph vessels. Each lobule was formed of multiple coalesced acini and intermingled pale stained areas of islets of Langerhans (Fig.1A and 1B). The acinar cells were truncated pyramidal with apical acidophilic and basal basophilic cytoplasm. Their nuclei were rounded and basal with prominent nucleoli (Fig. 1B'). In the islets of Langerhans, the central cells were either gathered around the blood capillaries as follicles or irregularly clustered. The centrally located cells had slightly dark basophilic rounded nuclei and acidophilic cytoplasm. The fewer peripherally located cells were closely adjacent together in cords. Their nuclei were oval and darkly basophilic (Fig. $1 \mathrm{~B}$ and $1 \mathrm{~B})$.

In Gr IIa, the acini appeared deformed and shrunken (Fig. 2A). The acinar cells were distended. Their cytoplasm was mainly acidophilic with faint basal basophilia. Their nuclei were small and darkly basophilic (Fig. 2B). The islets cells were deeply acidophilic and their nuclei were small and dark. The blood capillaries were dilated (Fig. 2C). In Gr IIb, the acini appeared less arranged (Fig. 2D). Their cytoplasm was acidophilic and their nuclei were darkly basophilic (Fig. 2E). The islets cells appeared distended with pale acidophilic cytoplasm and pale basophilic nuclei (Fig. 2F). Examination of the pancreatic tissues from $\mathrm{Gr}$ IIc revealed more shrinkage of acinar cells with less basal basophilic cytoplasm and darkly basophilic stained nuclei (Fig. 2G and 2H). Small aggregations of the islets cells that had pale acidophilic cytoplasm and pale basophilic nuclei were seen (Fig. 2I).

\section{Immunostained sections}

The insulin-positive reaction was localized in the cytoplasm of centrally located cells (Fig. 3A, B, C, and D). The reaction was intense in the Orx groups (Fig. 3B, C and D). Statistically, optical density of insulin immunopositive reactions was significantly increased in the Orx groups by comparison with the Gr I. The mean area \% of insulin immunopositive reaction was nonsignificantly decreased in Orx groups when compared to Gr I (Table 4). 
The immunopositive reaction with anti-glucagon protein was restricted in the cytoplasm of the peripherally located cells that formed a mantle in all studied groups (Fig. 3E, F, G and H). The mean area \% of glucagon immunopositive reaction was significantly decreased in Gr IIa by comparison with Gr I. While, Gr IIb and Gr IIc showed non-significant decrement when compared with Gr IIa (Table 4). To localize the apoptotic cells, immunostaining with anti-ss-DNA was performed. In the
Gr I, the apoptotic nuclei were hardly seen (Fig. 3I). On the contrary, the Orx groups showed numerous apoptotic nuclei in islets especially in the peripherally located cells and in the nuclei of some acinar cells (Fig. $3 \mathrm{~J}, \mathrm{~K}$ and L). The mean area $\%$ of ssDNA immunopositive reaction in the Gr IIa was significantly higher than that in Gr I. Compared to Gr IIa, the mean area \% of ssDNA immunopositive reaction of the Gr II b and Gr IIc increased non-significantly (Table 4).

Table 1: A list of antibodies, sources, dilutions, antigen retrieval and temperature used

\begin{tabular}{lccc}
\hline Antibodies & Sources & Dilutions & Antigen retrieval, temperature, time \\
\hline Anti- insulin protein (ab216418) & Abcam, USA & $1: 200$ & Citrate buffer (pH 6.0), 95 $5^{\circ} \mathrm{C}, 20 \mathrm{~min}$. \\
Anti-glucagon protein (ab48287) & Abcam, USA & $1: 500$ & Citrate buffer (pH 6.0), 105 ${ }^{\circ} \mathrm{C}, 20 \mathrm{~min}$. \\
Anti-rabbit ss-DNA & IBL -Fujioka, Japan & $1: 200$ & No antigen retrieval and heat used \\
\hline
\end{tabular}

Table 2: Statistical analysis of body mass of the studied groups

\begin{tabular}{|c|c|c|c|c|}
\hline Body mass & Gr I & Gr IIa & Gr IIb & Gr IIc \\
\hline Body mass before surgery ( $g$ ) & \multicolumn{4}{|c|}{$441.95 \pm 98.82$} \\
\hline Body mass after surgery (g) & $447.40 \pm 5.35$ & $399.40 \pm 5.85^{*}$ & $462.60 \pm 15.20^{\#}$ & $474.00 \pm 5.64^{\#}$ \\
\hline
\end{tabular}

Mean \pm SE; $\mathrm{n}=6$ /group; significant difference when $P \leq 0.05$; *significant when compared with control group (Gr I); \#significant when compared with Gr IIa.

Table 3: Statistical analysis of biochemical parameters of the studied groups

\begin{tabular}{lcccc}
\hline & Gr I & Gr IIa & Gr Ilb & Gr IIc \\
Parameters & $2.54 \pm 0.20$ & $0.04 \pm 0.014^{*}$ & $0.025 \pm 0.005^{*}$ & $0.022 \pm 0.006^{*}$ \\
Serum free T level $(\mathrm{ng} / \mathrm{mL})$ & $92.34 \pm 1.41$ & $142.36 \pm 1.75^{*}$ & $144.54 \pm 1.51^{*}$ & $146.98 \pm 1.70^{*}$ \\
Plasma glucose level (mg/dl) & $157.5 \pm 2.32$ & $128.33 \pm 2.74^{*}$ & $122.5 \pm .99^{*}$ & $111.0 \pm 1.15^{* \#}$ \\
Serum SOD level (U/ ml) & $8.33 \pm 0.33$ & $16.17 \pm 0.48^{*}$ & $17.7 \pm 0.60^{*}$ & $19.17 \pm 19.17^{*}$ \\
\hline
\end{tabular}

Mean $\pm \mathrm{SE} ; \mathrm{n}=6$ /group; significant difference when $P \leq 0.05 ; *^{*}$ significant when compared with control group (Gr I); ${ }^{*}$ significant when compared with Gr IIa. 
Table 4: Statistical analysis of the insulin optical density, area \%of insulin, glucagon and ss-DNA immunopositive reactions in the islets of pancreas of all studied groups.

\begin{tabular}{lccc}
\hline Groups & Gr I & Gr IIa & Gr IIb \\
Parameters & $2.51 \pm 0.005$ & $2.69 \pm 0.018^{*}$ & $2.65 \pm 0.0095^{*}$ \\
Insulin optical density & $13.1 \pm 3.20$ & $11.14 \pm 3.24$ & $9.44 \pm 0.65$ \\
Insulin +ve area $\%$ & $6.07 \pm 0.73$ & $2.49 \pm 0.84^{*}$ & $2.40 \pm 0.43^{*}$ \\
Glucagon +ve area $\%$ & & $1.08 \pm 0.12^{*}$ & $1.13 \pm 0.13^{*}$ \\
ssDNA +ve area $\%$ & $0.001 \pm 0.000$ & $1.37 \pm 0.25^{*}$ \\
\hline
\end{tabular}

Mean \pm SE; $\mathrm{n}=6$ /group; significant difference when $P \leq 0.05 ; *$ significant when compared with control.
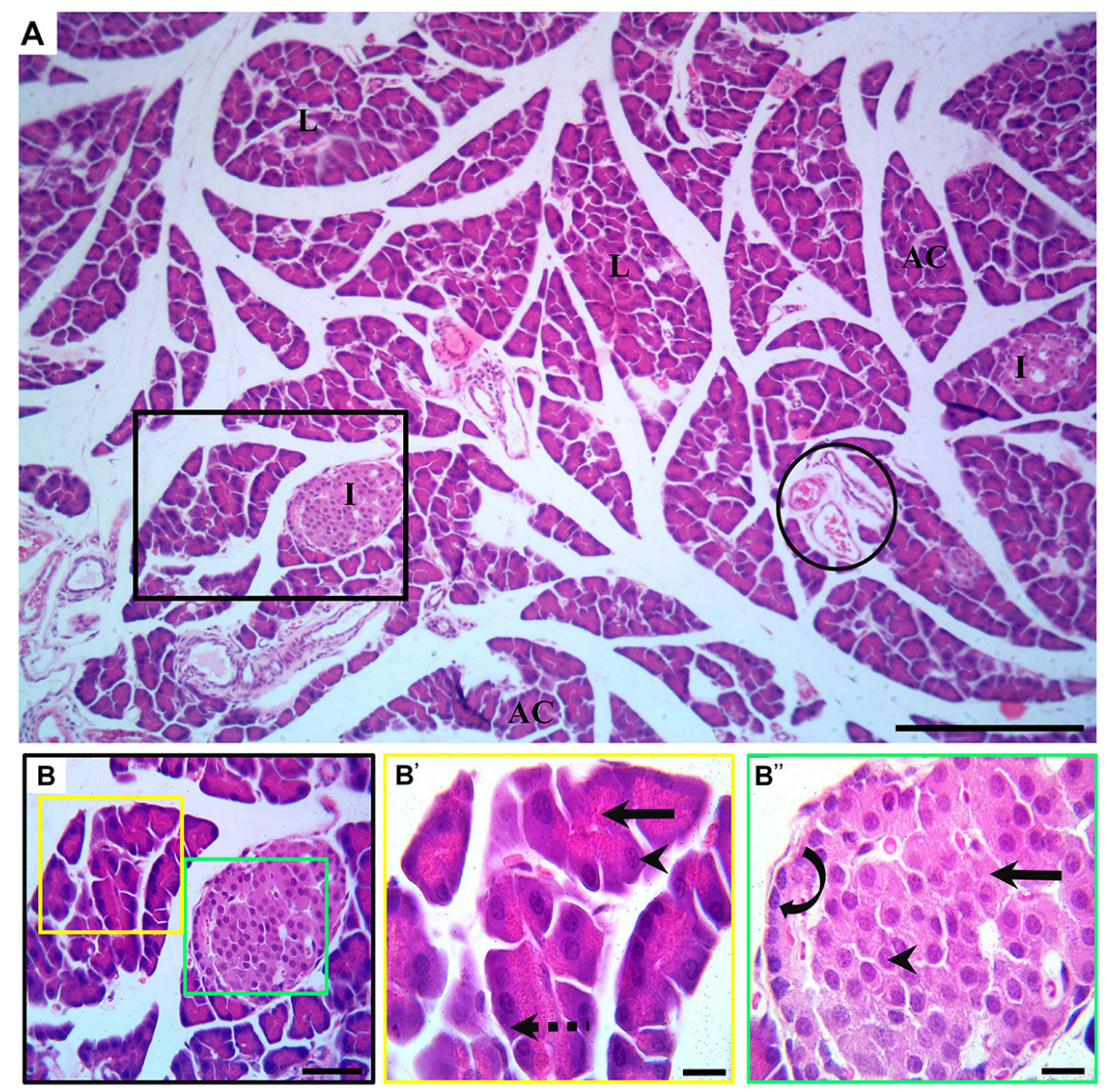

Fig. 1: Photomicrographs of a section in the pancreas of a control rat stained by H \& E. (A) Showing multiple lobules (L) separated by thin connective tissue septa that housed blood and lymph vessels (circle). Each lobule composed of coalesced acini (AC) and intermingled with islets of Langerhans (I). (B) A higher magnification of the black boxed area in A. (B') A higher magnification of the yellow boxed area in B showing the truncated pyramidal cells with apical acidophilic (arrow) and basal basophilic (dashed arrow) cytoplasm that contained basal rounded nuclei with prominent nucleoli (arrowhead). (B") A higher magnification of the green boxed area in B showing the central cells with slightly acidophilic cytoplasm (arrow) and slightly dark basophilic rounded nuclei (arrowhead), while the peripheral cells have oval and darkly basophilic stained nuclei (closed arrow). Bars: $A=200 \mu \mathrm{m}, \mathrm{B}=50 \mu \mathrm{m}, \mathrm{B}^{\prime}$ and $\mathrm{B}^{\prime \prime}=30 \mu \mathrm{m}$. 

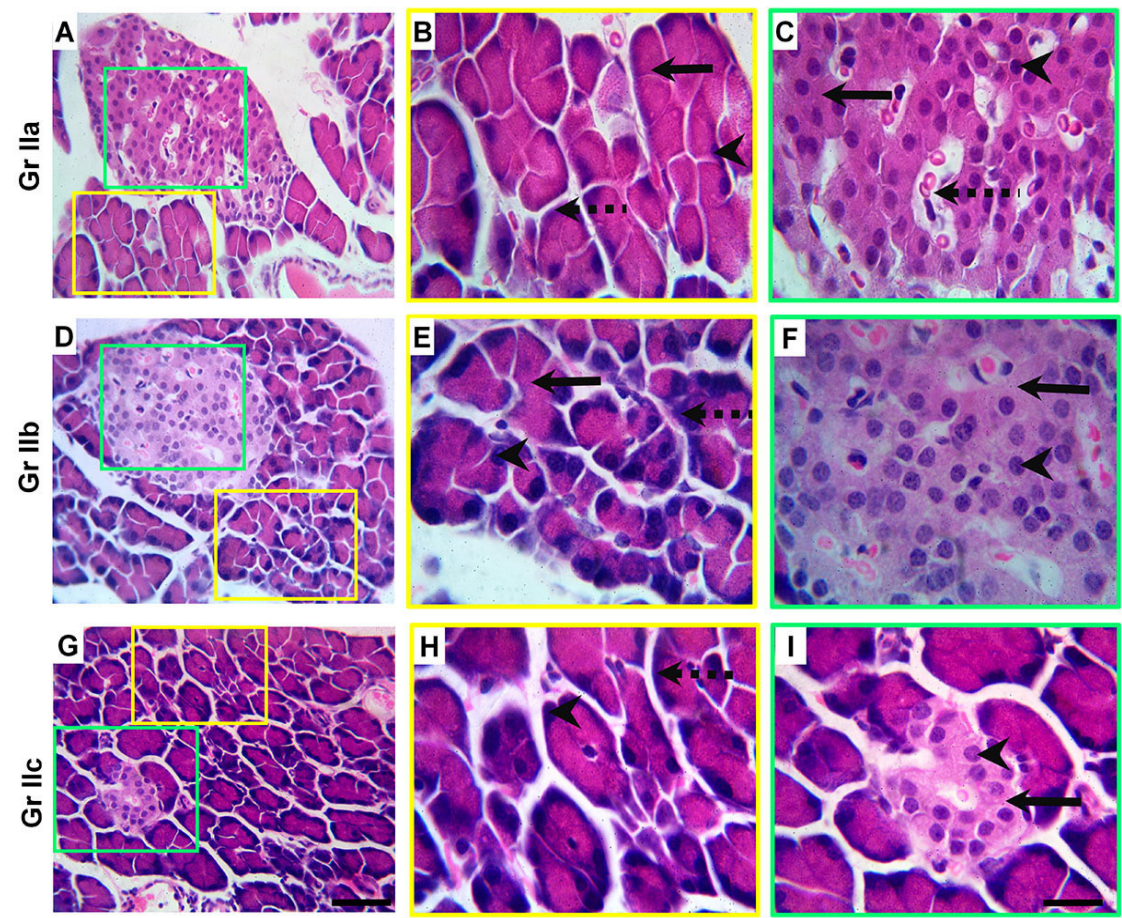

Fig. 2: Photomicrographs of pancreases of bilateral orchiectomized rats H\&E stained. (A-C) Gr IIa. (B) A higher magnification of the yellow boxed area in A showing distended acini with apical acidophilic (arrow) and faint basal basophilic cytoplasm (dashed arrow) with small and darkly basophilic stained nuclei (arrowhead). (C) A higher magnification of the green boxed area in A showing islet cells with deeply acidophilic cytoplasm (arrow) and small darkly basophilic nuclei (arrowhead). Notice the dilated blood capillaries (dashed arrow). (D-F) Gr IIb. (E) A higher magnification of the yellow boxed area in D showing acini with apical acidophilic (arrow) and less basal basophilic cytoplasm (dashed arrow) with oval dark basophilic nuclei (arrowhead). (F) A higher magnification of the green boxed area in D showing the islet cells with pale acidophilic cytoplasm (arrow) and pale basophilic nuclei (arrowhead). (G-I)Gr IIc. (H) A higher magnification of the yellow boxed area in G showing acinar cells with declared less basal basophilic cytoplasm (dashed arrow) and small dark basophilic nuclei (arrowhead). (I) A higher magnification of the green boxed area in $\mathrm{G}$ showing small aggregation of islet cells. Their cytoplasm is pale acidophilic (arrow) and contains pale basophilic nuclei (arrowhead). Bars: A, D \& G $=50 \mu \mathrm{m}$; B, C, E, F, H and I $=30 \mu \mathrm{m}$
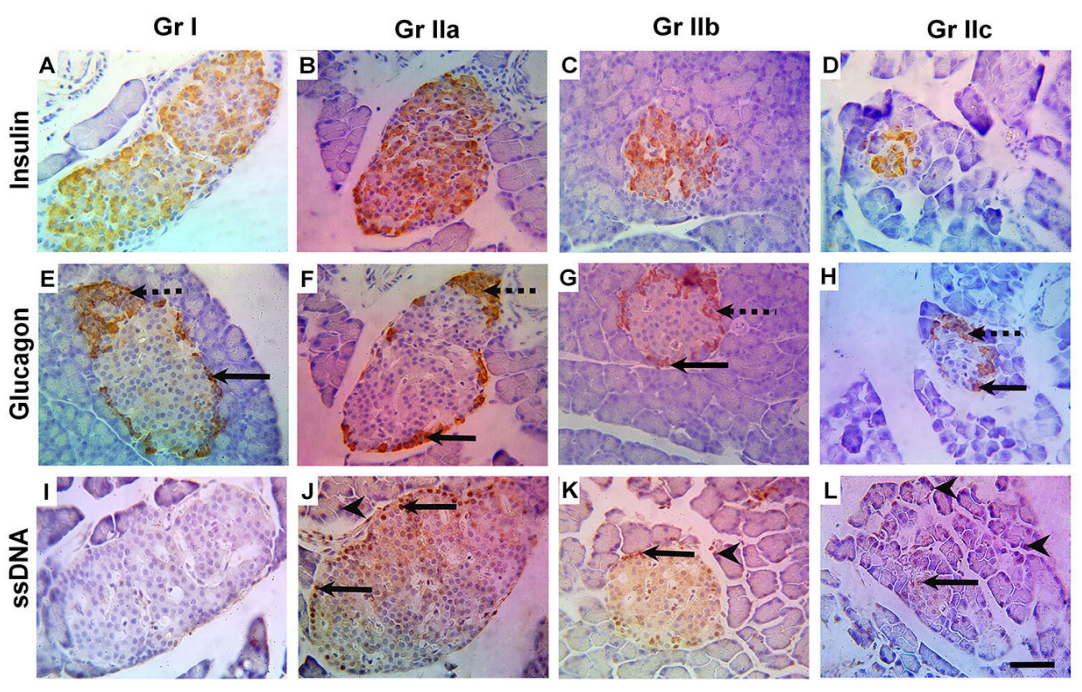

Fig. 3: Photomicrographs of immunostained sections of pancreatic islets in all studied groups. (A-D) Showing insulin-positive reactions in the cytoplasm of centrally located cells. Notice the intense reaction in orchiectomized groups (B, C \&D). (E-H) Showing glucagon-positive reaction restricted in the cytoplasm of peripherally located cells (arrow) and in cells forming the mantle (dashed arrows). (I) Showing negative reaction with anti-ssDNA in the control group. (J-L) Showing positive reaction with anti- ssDNA restricted to the nuclei of the peripherally located cells (arrows) and in some acinar cells (arrowhead) in orchiectomized groups. Bars $=50 \mu \mathrm{m}$. 


\section{DISCUSSION}

This study revealed that orchidectomy affected both exocrine and endocrine pancreatic tissue. The undetectable $T$ levels in the Orx groups were in accordance with previous researchers ${ }^{[10,22]}$. They proved depletion of testosterone up to eight months postoperative. Despite production of testosterone by both testicles and adrenal glands, the reported data in a recent study on orchiectomized rats was surprising, whereas their conclusion implies that $\mathrm{T}$ deficiency decreases expression of adrenal genes confined to lipids and cholesterol metabolism. Consequently, decreased cholesterol metabolism will lead to decreased $\mathrm{T}$ production by adrenal gland. More investigations are necessary to clarify the compensatory role of the adrenal gland after orchidectomy ${ }^{[23]}$.

The glucagon-like peptide-1 (GLP1) is an incretin hormone secreted from intestine. Via androgen receptor in $\beta$ cells, dihydrotestosterone activates it. Consequently, GLP1 will stimulate insulin secretion and inhibit glucagon secretion $^{[24]}$. The observable hyperglycemia in the investigated Orx groups was in accordance with[25], who reported a significant insulin resistance in elderly men with reduced $\mathrm{T}$ level. Consequently, these patients will suffer from metabolic syndrome and type II diabetes which considered a risk factor for cardiovascular diseases.

In clinical studies with long-term ADT, the incidence rates of hyperglycemia, hyperinsulinemia, and metabolic syndrome were augmented. Even in T-deficiency independently, whether it is from the metabolic disorders or obesity, impaired fasting glucose and glucose intolerance were recorded ${ }^{[8,26,27]}$. Xia and colleagues correlated between low serum $\mathrm{T}$ level in elderly and insulin resistance ${ }^{[28]}$. Surprisingly, normal blood glucose levels with hyperinsulinemia in patients with prostatic cancer submitted to testectomy was documented ${ }^{[29]}$. Moreover, in orchidectomized adult rats, normoglycemia was noted after eight months of ablation. Modifications of body composition after $\mathrm{T}$ deficiency, including accumulation of visceral fat which consequently affected glucose metabolism might be the cause ${ }^{[22]}$. Initial defects in insulin secretion regardless the causes are associated with increases in glucagon secretion that followed by impaired glucose tolerance ${ }^{[30]}$.

Oxidative stress is a basic process involved in many tissue injuries. Unfortunately, the pancreatic $\beta$ cells possess very low expression levels of antioxidant enzymes ${ }^{[31]}$. In the Orx animals of this study, an imbalance in the ROS system was detected. These data were coincided with Son et $a l^{[10]}$, who proved that orchiectomy in mice accelerated oxidative injury in the brain. They claimed that $\mathrm{T}$ is a strong antioxidant. It could protect the tissue against oxidative damage even in stress conditions. In this work, the oxidative alterations were in line with the significant increase in single-strand breaks of DNA observed in orchiectomized rats.

Since insulin is considered as a local trophic factor via insulin-acinar portal system, a lack of local insulin secretion due to $\mathrm{T}$ insufficiency was found to induce acinar atrophy ${ }^{[32]}$. In our work, the shrunken and deformed acini that lined by less basophilic acinar cells with small dark basophilic nuclei indicated low activity of exocrine pancreas in Orx groups. Recently, Talukdar and Reddy ${ }^{[33]}$ clarified the association between exocrine pancreatic insufficiency and hyperglycemia in humans. Vice versa, impairment of the exocrine pancreas will lead to mal-digestion of fat and protein. Consequently, the secretion of incretins which largely depends on normal fat and protein digestion will be affected ${ }^{[24]}$. Furthermore, any exocrine pancreatic disorders including; inflammation, tumors, or cystic fibrosis can induce DM named type 3 (a pancreatogenic diabetes) ${ }^{[34]}$. Unfortunately, exocrine pancreatic insufficiency did not depend on the duration of diabetes ${ }^{[35,36]}$.

In group IIa of this work, the increased density of insulin immunostaining is coincided with accumulation of insulin secretion inside granules and its failure of secretion after $\mathrm{T}$-deficiency ${ }^{[24]}$. Whereas, $\mathrm{T}$ hormone proven to increase glucose-stimulated insulin secretion via the interaction between the extra-nuclear androgen receptor and the GLP1 receptor in $\beta$ cells. Gao and his colleagues considered the hypercholesterolemia as another cause of hypertrophy of $\beta$ cells in rabbit ${ }^{[37]}$. Alexandersen and Christiansen ${ }^{[38]}$ reported increased low-density lipoprotein fraction in $\mathrm{T}$ deficiency due to hypogonadism.

Interestingly, $\alpha$ cells are more affected than $\beta$ cells in the investigated Orx groups. Immunopositive staining with anti-ssDNA (a nuclear apoptotic marker) was mostly in cells peripherally located in the islets. These apoptotic cells are not restored even 10 weeks postoperatively. This suggested that decreased of $\alpha$ cells index occurred was due to breaks in single stranded DNA. In accordance, Inoue ${ }^{[39]}$ reported decreased of all pancreatic parameters in castrated mice when compared to sham-operated mice. Decrement of epidermal growth factor secreted from rat submaxillary salivary gland as a result of decreased quantity of androgen receptor following testectomy might be the cause ${ }^{[40]}$.

Several animal studies have proved that testosterone acts as a vasodilator on coronary, the thoracic aorta and pulmonary arteries ${ }^{[41]}$. Contradictory, in this work, dilation of islets blood vessels was noted in Orx group.

\section{CONCLUSION}

Orchiectomy-induced testosterone deficiency affects both exocrine and endocrine pancreatic portions and is associated with a risk for pancreatogenic diabetes (type III). Therefore, we should be more cautious before 
performing orchiectomy in humans or animals.

\section{CONFLICT OF INTEREST}

There are no conflicts of itnerest.

\section{REFERENCES}

1. Wang, C., Nieschlag, E., Swerdloff, R., Behre, H.M., Hellstrom, W.J., Gooren, L.J., et al. Investigation, treatment and monitoring of lateonset hypogonadism in males. International journal of andrology. 2009, 32, 1-10.

2. Schubert, M., Jockenhövel, F. Late-onset hypogonadism in the aging male $(\mathrm{LOH})$ : definition, diagnostic and clinical aspects. Journal of endocrinological investigation. 2004, 28, 23-7.

3. Traish, A.M., Guay, A., Feeley, R., Saad, F. The dark side of testosterone deficiency: I. Metabolic syndrome and erectile dysfunction. Journal of Andrology. 2009, 30, 10-22.

4. Staerman, F., Léon, P. Andropause (androgen deficiency of the aging male): diagnosis and management. Minerva medica. 2012, 103, 333-42.

5. Gravis, G., Fizazi, K., Joly, F., Oudard, S., Priou, F., Esterni, B., et al. Androgen-deprivation therapy alone or with docetaxel in non-castrate metastatic prostate cancer (GETUG-AFU 15): a randomised, open-label, phase 3 trial. The lancet oncology. 2013, 14, 149-58.

6. Rajesh, R., Nigam, D. Bilateral orchiectomy versus total androgen blockade in the management of metastatic cancer prostate. International Surgery Journal. 2016, 3, 841-5.

7. Jang, H., Bae, W.J., Kim, S.J., Yuk, S.M., Han, D.S., Ha, U., et al. The effect of anthocyanin on the prostate in an andropause animal model: rapid prostatic cell death by apoptosis is partially prevented by anthocyanin supplementation. The world journal of men's health. 2013, 31, 239-46.

8. Keating, N.L., O'Malley, A.J., Freedland, S.J., Smith, M.R. Diabetes and cardiovascular disease during androgen deprivation therapy: observational study of veterans with prostate cancer. Journal of the National Cancer Institute. 2009.

9. Potosky, A.L., Haque, R., Cassidy-Bushrow, A.E., Yood, M.U., Jiang, M., Tsai, H.-T., et al. Effectiveness of primary androgen-deprivation therapy for clinically localized prostate cancer.
Journal of Clinical Oncology. 2014, JCO. 2013.52. 5782 .

10. Son, S.W., Lee, J.S., Kim, H.G., Kim, D.W., Ahn, Y.C., Son, C.G. Testosterone depletion increases the susceptibility of brain tissue to oxidative damage in a restraint stress mouse model. Journal of neurochemistry. 2016, 136, 106-17.

11. Seymour, P.A. Sox9: a master regulator of the pancreatic program. The review of diabetic studies: RDS. 2014, 11, 51.

12. Caiaffo, V., Duarte Ribeiro de Oliveira, B., Bezerra de Sa, F., Evencio Neto, J., Amaro da Silva Junior, V. Marine Food Protection in Testicular Damages Caused by Diab e tes Mellitus. Current Diabetes Reviews. 2017, 13, 566-72.

13. Long, L., Wang, J., Lu, X., Xu, Y., Zheng, S., Luo, C., et al. Protective effects of scutellarin on type II diabetes mellitus-induced testicular damages related to reactive oxygen species/Bcl-2/Bax and reactive oxygen species/microcirculation/ staving pathway in diabetic rat. Journal of diabetes research. 2015, 2015.

14. Choobineh, H., Gilani, M.A.S., Pasalar, P., Jahanzad, I., Ghorbani, R., Hassanzadeh, G. The Effects of Testosterone on Oxidative Stress Markers in Mice with Spinal Cord Injuries. International journal of fertility and sterility. $2016,10,87$.

15. Morimoto, S., Mendoza-Rodriguez, C., Hiriart, M., Larrieta, M., Vital, P., Cerbon, M. Protective effect of testosterone on early apoptotic damage induced by streptozotocin in rat pancreas. Journal of Endocrinology. 2005, 187, 217-24.

16. Villareal, D.T., Holloszy, J.O. Effect of DHEA on abdominal fat and insulin action in elderly women and men: a randomized controlled trial. Jama. 2004, 292, 2243-8.

17. Genazzani, A.D., Lanzoni, C., Genazzani, A.R. Might DHEA be considered a beneficial replacement therapy in the elderly? Drugs \& aging. 2007, 24, 173-85.

18. Pitteloud, N., Hardin, M., Dwyer, A.A., Valassi, E., Yialamas, M., Elahi, D., et al. Increasing insulin resistance is associated with a decrease in Leydig cell testosterone secretion in men. The Journal of Clinical Endocrinology and Metabolism. 2005, 90, 2636-41.

19. Kupelian, V., Page, S.T., Araujo, A.B., Travison, 
T.G., Bremner, W.J., McKinlay, J.B. Low sex hormone-binding globulin, total testosterone, and symptomatic androgen deficiency are associated with development of the metabolic syndrome in nonobese men. The Journal of Clinical Endocrinology and Metabolism. 2006, 91, 843-50.

20. Foley, P. Common surgical procedures in rodents. Laboratory Animal Medicine and Management. Office of Animal Research Education and Compliance, University of Virginia, Charlottesville, VA, USA: International Veterinary Information Service, Ithaca NY (www. ivis. org). 2005.

21. Bancroft, J.D., Layton, C. The hematoxylins and eosin. Bancroft's Theory and Practice of Histological Techniques, Expert Consult: Online and Print, 7: Bancroft's Theory and Practice of Histological Techniques. 2012, 173.

22. Alberti, L., Magalhães Veloso, D., De Souza Vasconcellos, L., Carvalho Garcia, D., Petroianu, A. Morphofunctional and Metabolic Alterations after Orchiectomy. Peertechz J Biol Res Dev 1: 001-006. 001, 2016, 30.

23. Jopek, K., Celichowski, P., Szyszka, M., Tyczewska, M., Milecka, P., Malendowicz, L.K., et al. Transcriptome Profile of rat adrenal evoked by gonadectomy and Testosterone or estradiol replacement. Frontiers in endocrinology. 2017, 8.

24. Navarro, G., Xu, W., Jacobson, D.A., Wicksteed, B., Allard, C., Zhang, G., et al. Extranuclear actions of the androgen receptor enhance glucosestimulated insulin secretion in the male. Cell metabolism. 2016, 23, 837-51.

25. Zitzmann, M., Faber, S., Nieschlag, E. Association of specific symptoms and metabolic risks with serum testosterone in older men. The Journal of Clinical Endocrinology and Metabolism. 2006, 91, 4335-43.

26. Shahani, S., Braga-Basaria, M., Basaria, S. Androgen deprivation therapy in prostate cancer and metabolic risk for atherosclerosis. The Journal of Clinical Endocrinology and Metabolism. 2008, 93, 2042-9.

27. Ho, C.-H., Yu, H.-J., Wang, C.-Y., Jaw, F.-S., Hsieh, J.-T., Liao, W.-C., et al. Prediabetes is associated with an increased risk of testosterone deficiency, independent of obesity and metabolic syndrome. PloS one. 2013, 8, e74173.

28. Xia, J.w., Tan, S.j., Zhang, X.1., Jun, T., Sun, X.k.,
Ling, W. Correlation of serum testosterone with insulin resistance in elderly male type 2 diabetes mellitus patients with osteoporosis. Journal of diabetes investigation. 2015, 6, 548-52.

29. Smith, M.R., Finkelstein, J.S., McGovern, F.J., Zietman, A.L., Fallon, M.A., Schoenfeld, D.A., et al. Changes in body composition during androgen deprivation therapy for prostate cancer. The Journal of Clinical Endocrinology \& Metabolism. 2002, 87, 599-603.

30. Knop, F., Vilsbøll, T., Larsen, S., Madsbad, S., Holst, J.J., Krarup, T. Glucagon suppression during OGTT worsens while suppression during IVGTT sustains alongside development of glucose intolerance in patients with chronic pancreatitis. Regulatory peptides. 2010, 164, 144-50.

31. Kajimoto, Y., Kaneto, H. Role of Oxidative Stress in Pancreatic $\beta$-Cell Dysfunction. Annals of the New York Academy of Sciences. 2004, $1011,168-76$.

32. Andren-Sandberg, A., Hardt, P.D. Second Giessen International Workshop on Interactions of Exocrine and Endocrine Pancreatic Diseases. J Pancreas (Online). 2008, 9, 541-75.

33. Talukdar, R., Reddy, D.N. Pancreatic Exocrine Insufficiency in Type 1 and 2 Diabetes: Therapeutic Implications. Journal of The Association of Physicians of India. 2017, 65, 64.

34. Association, A.D. Standards of medical care in diabetes-2016 abridged for primary care providers. Clinical diabetes: a publication of the American Diabetes Association. 2016, 34, 3.

35. Rickels, M.R., Bellin, M., Toledo, F.G., Robertson, R.P., Andersen, D.K., Chari, S.T., et al. Detection, evaluation and treatment of diabetes mellitus in chronic pancreatitis: recommendations from PancreasFest 2012. Pancreatology. 2013, 13, 336-42.

36. Gudipaty, L., Rickels, M.R. Pancreatogenic (Type 3c) Diabetes. Pancreapedia: The Exocrine Pancreas Knowledge Base. 2015.

37. GAO, T., LU, Y.-S., DONG, Z.-B., GONG, F.-Y., QU, R.-B. The Influence of Hypercholesterolemia to Rabbit Islet $\beta$ Cell and Intervention Effect of Atorvastatin. Chinese Journal of Arteriosclerosis. 2013, 4, 008.

38. Alexandersen, P., Christiansen, C. The aging male: testosterone deficiency and testosterone 
replacement. An up-date. Atherosclerosis. 2004, 173, 157-69.

39. Inoue, T., Zakikhani, M., David, S., Algire, C., Blouin, M.J., Pollak, M. Effects of castration on insulin levels and glucose tolerance in the mouse differ from those in man. The Prostate. $2010,70,1628-35$.

40. Zhu, Y. Castration affects the expression of androgen receptor and epidermal growth factor in rat submaxillary salivary gland. Zhonghua nan ke $x u e=$ National journal of andrology. 2006, 12, 540-1, 4.

41. Jones, R.D., Pugh, P.J., Jones, T.H., Channer, K.S. The vasodilatory action of testosterone: a potassium-channel opening or a calcium antagonistic action? British journal of pharmacology. 2003, 138, 733-44. 
الملخص العربى

متابعه التغيرات التركيبيه للبنكرياس في نموذج الإياس الأكري للجرذ الناجمه عن استئصال كلا

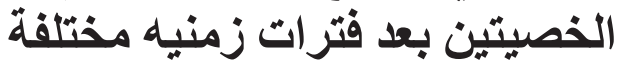

\author{
زينب عبد الله جودة1 ، نسمه إبراهيم النصيرى2²، محمد السيد على خليفة1 \\ 1قسم الهستولوجى وبيولوجيا الخلية ، كلية الطب ، 2قسم الهستولوجى وعلم الخلية ، كلية الطب الطب

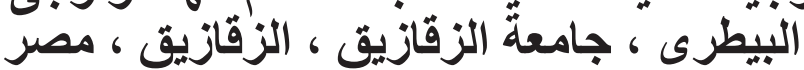

المقدمة: يتشارك البنكرياس و الغدد التناسليه في نفس المنافع.

الهُف من البحث: متابعه التغير ات التركيبيه للبنكرياس بعد فترات الفيك زمنيه مختلفة من عملية إستئصال الخصيتين.

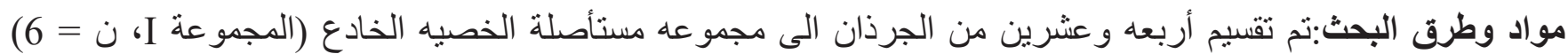

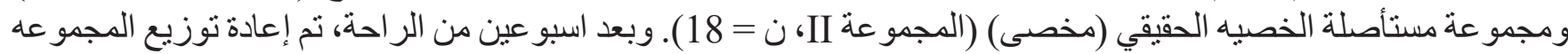

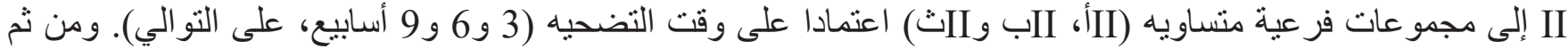
تم تمرير لعينات البنكرياس وصباغتها بصبغه الهيماتوكسيلين والإيوسين و الصبغه المناعية المباتية المضادة لبروتينات الإنسولين

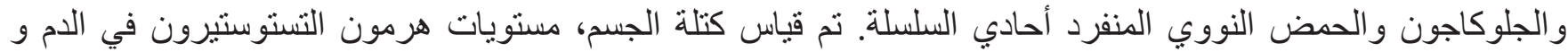

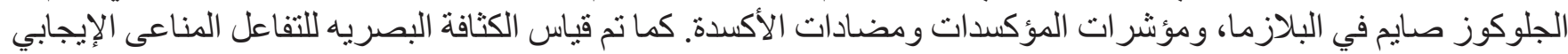

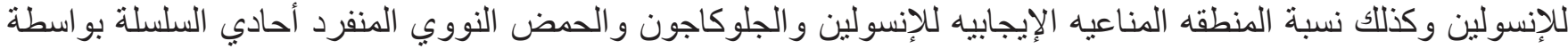

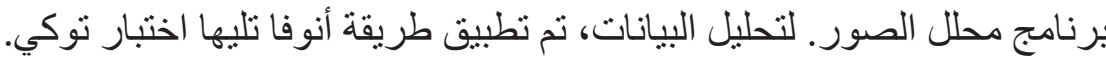

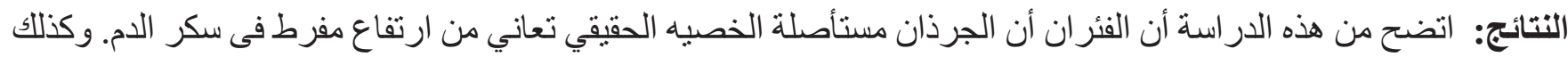

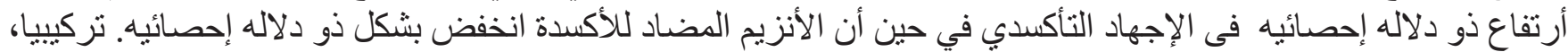

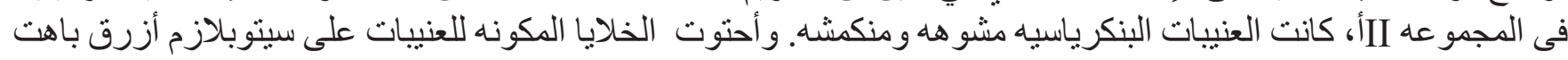

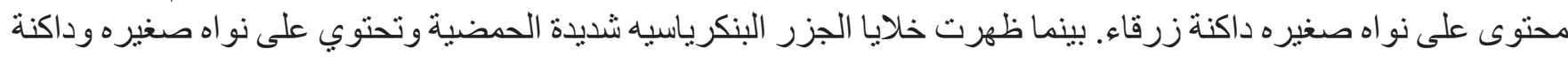

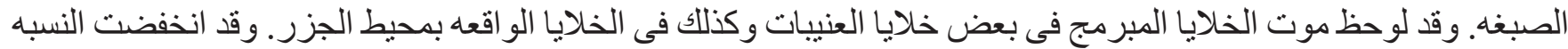

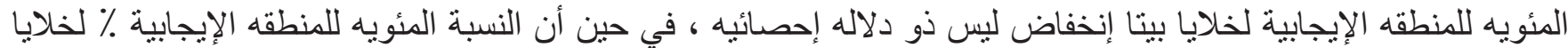

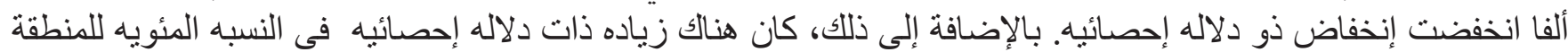

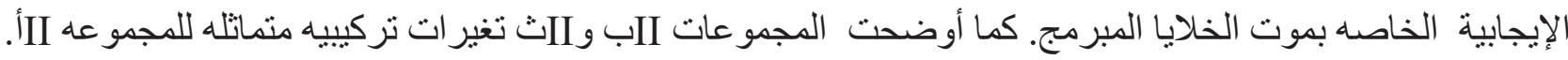

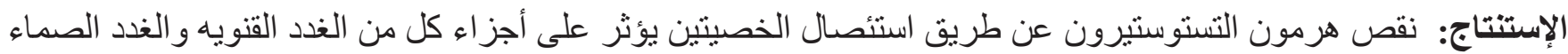

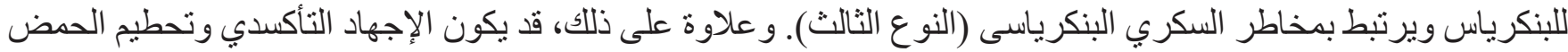

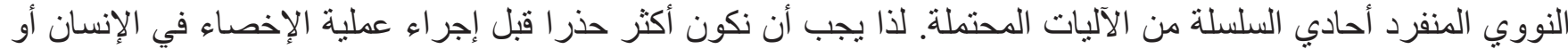
الحيوان. 